\title{
EFFECTS OF ROTATIONAL GRAZING ON RODENTS AND RAPTORS IN A COASTAL GRASSLAND
}

\author{
Matthew D. Johnson ${ }^{1}$ and Christa M. Horn ${ }^{2,3}$
}

\begin{abstract}
We conducted a 4-year experiment to assess the impacts of rotational cattle grazing on rodents and raptors in a mesic coastal grassland in northwestern California. Live-trapping indicated that rodent abundance declined by $69 \%$ on the grazed area and increased by $14 \%$ on the ungrazed area. Raptor use of the grazed area declined by $15 \%$ and increased on the ungrazed area by $63 \%$. Measures of giving-up density indicated that rodents perceived a $25 \%$ higher predation risk on grazed area than on ungrazed area, but raptor hunting surveys indicated that risk of depredation from raptors was 2.5 times lower in the grazed habitat, suggesting that rodents use indirect vegetative cues to assess risk.
\end{abstract}

Key words: rotational grazing, giving-up density, forage, predation risk, raptors, rodents, California, Microtus californicus, Short-eared Owl, White-tailed Kite.

The use of livestock grazing to manage habitats for wildlife remains controversial, in part because its effects vary markedly among wildlife species and regions (Severson 1990, Kirby et al. 1992). Natural resource managers must predict its consequences and balance positive and negative effects accordingly. For example, rotational cattle grazing alters vegetation in ways that can benefit waterfowl (Kantrud 1986, Kirby et al. 1992, Ignatiuk and Duncan 2001, Carroll et al. 2007), but it reduces tall grasses favored by some raptors and rodents (Saab et al. 1995, Evans et al. 2006). Effects of rotational grazing on raptors and rodents have received attention in arid environments (Bock et al. 1984, Fleischner 1994, Bock and Bock 1999, Jones 2000, Jones et al. 2003), but much less is known of its effects in mesic grasslands like those in coastal California and the Pacific Northwest (Ostfeld and Klosterman 1986, Fehmi and Bartolome 2002, Hayes and Holl 2003), and no study has experimentally investigated the effects of rotational grazing on wildlife in coastal California.

Breeding density and success of several raptor species have been linked directly to rodent abundance in grasslands (reviewed in Newton 1998). However, it remains unknown to what extent livestock grazing may indirectly affect prey availability for raptors reliant on rodents in grasslands (Saab et al. 1995, Newton 1998, Evans et al. 2006). Our objective was to exam- ine the effects of rotational grazing on raptor use, rodent abundance, and risk of rodent depredation in a mesic grassland in northwestern California.

\section{STUdy AREA}

Our study area comprised 102 ha of the Mad River Slough Wildlife Area, near the town of Arcata in coastal Humboldt County, California. The area was divided into a grazed (54 ha) treatment area and an adjacent, similarly shaped ungrazed (48 ha) treatment area. The land is a former ranch that was acquired by the California Department of Fish and Game and had been ungrazed since the late 1980s. By 2002 the grassland community had advanced in succession to a 0.6-1.0-m-tall rank grassland dominated by Holcus lanatus (34\%, approximate percent composition), Alopecurus carolinianus (20\%), Elymus spp. (12\%), Trifolium repens (8\%), Circium vulgare (7\%), Festuca spp. (7\%), Lotus corniculatus (6\%), and Lolium perenne (5\%). The area receives an average rainfall of about $120 \mathrm{~cm}$ annually (NOAA 2007).

Fences were erected in the grazed portion of the study area from May to July 2003 to create 14 paddocks of approximately 2.2 ha (5.5 acres) and 1 large paddock (24 ha) at one end of the grazed area. Cattle (initially beef cows; dairy heifers after 2004) were introduced to the grazed area beginning in July 2003. Stocking

\footnotetext{
${ }^{1}$ Department of Wildlife, Humboldt State University, 1 Harpst Street, Arcata, CA 95521. E-mail: mdj6@humboldt.edu

${ }^{2}$ Earth Systems, Stanford University, Stanford, CA 95405.

${ }^{3}$ Present address: 115 NW Oregon Ave., Bend, OR 97701.
} 
numbers varied from 60-100 animal units (AUs) depending on the season. The number of days cattle grazed a given paddock varied seasonally and among individual paddocks, but it was generally $2-3$ days in spring, $4-6$ days in summer, and 0-3 days in winter, depending on rainfall. The time elapsed since a given paddock was grazed in our rotation ranged from 0 to 84 days. In summer 2004 and sporadically in winter months when rain flooded the northern paddocks, the cattle spent a disproportionate amount of time in the large paddock or were removed from the area entirely.

\section{MeTHODS}

We conducted wildlife surveys both before and after the onset of grazing. For all procedures, we conducted surveys simultaneously on the grazed and ungrazed treatment to control for potentially confounding factors such as weather. From October 2002 to August 2004, wildlife surveys were on a roughly 8-week cycle (15 sampling periods); from August 2004 to October 2006, sampling occurred roughly every 3 months (8 sampling periods).

We monitored small mammals on 6 randomly positioned $6 \times 6$ trapping grids ( 3 grazed and 3 ungrazed grids), with $10 \mathrm{~m}$ between grid points, so the trapping area was equivalent between grazed and ungrazed sides. On the grazed side, the randomization was constrained to ensure that a trapping grid included the intersection of 4 paddocks. No trapping was conducted when cattle were present in any of the 4 paddocks in a grid; therefore, 5-46 days had elapsed since grazing occurred when a given grid was trapped, depending on season (fewer days when cattle were rotated more quickly) and grid placement (grid 1, 22-46 days; grid 2, 16-32 days; grid 3, 5-10 days). In our analysis we did not focus on the time elapsed since grazing. Instead, we chose this design to represent the diverse conditions of paddocks in the rotation, while trapping on at least a portion of as many paddocks as was feasible (10 of 15 in our study) with stationary grids. The grids were $250-800 \mathrm{~m}$ apart from each other and remained in those positions for the duration of the study. Among the 231 rodents that were individually marked (eartags), none was ever recaptured in a different grid (M.D. Johnson unpublished data), so we assume there was little movement between grids.
Two Sherman ${ }^{\circledR}$ live-traps were placed at each grid point (72 per grid). Traps were opened within 2 hours of sunset and checked within 2 hours of sunrise. The trapping schedule alternated between 5-night trapping sessions and 4-night nontrapping sessions on each pair of grids in sequence for 27 nights, followed by a variable nontrapping period until the start of the next sampling period. On average, the total number of captures reached $90 \%$ of the 5-night total after the 4 th night, suggesting that 5 trapnights yielded adequate capture accumulation. Total trap effort was 360 trap-nights per grid per treatment per sampling period for a total of 49,680 trap-nights (23 sampling periods, 3 grids per treatment, 2 treatments). We identified trapped animals to species, trimmed a small patch of hair to distinguish previously trapped individuals, and released them at the point of capture. The hair regrew between sampling periods, so the trimming method only distinguished recaptures within a sample, and animals with regrown hair could have been tallied repeatedly among surveys (Bock et al. 2006). However, the number of individuals captured per unit trapping effort is a reliable index of abundance of rodents, even if repeat captures between sample periods are included (Hopkins and Kennedy 2004). Therefore, for comparative purposes we used the number of unique individuals captured (previously unmarked) per 100 trap-nights as an index of abundance in a sample period.

We assessed raptor activity in the area by counting all raptors visible from 14 counting stations distributed systematically $(100 \mathrm{~m}$ between stations, 7 in each treatment area). We conducted counts within 4 hours of sunrise on 2 consecutive mornings per sample period, with 2 observers alternating treatment areas between mornings. We only included birds perched within or flying directly over a treatment area in our analyses. Individual raptors could be detected from several stations, so we used the average of all 7 stations on a treatment area as an estimate of raptor activity on the treatment, rather than abundance of individual birds, for that sample period. In July and October 2004, we conducted thirty-two 60-minute surveys ( 8 per month per treatment) within 2 hours of sunset to record rate of raptor strikes and prey captures, calculated as the number observed per hour of observation per hectare of surveyed area. Strikes were indicated by a 
raptor landing on the ground in an attack position (e.g., kiting, pouncing, stooping), and we determined capture success by noting whether the raptor carried prey after take-off. Most raptors in the study area fly to a perch or nearby area to consume their captured prey (Clark 1975, Preston and Beane 1993, Crocoll 1994, Dunk 1995, Redpath et al. 2002), although Northern Harriers (Circus cyaneus) sometimes consume prey at the point of capture (MacWhirter and Bildstein 1996; personal observation).

We measured perceived predation risk to rodents by measuring the giving-up density (hereafter, GUD) of food in trays following methods developed by Brown and colleagues (Brown and Kotler 2004 and references therein). In short, the GUD is proportional to the food harvest rate at which an optimal forager should abandon a depletable patch of food. Predation risk is one of the costs of foraging, so under high perceived risk of predation, a forager will abandon a patch quickly, leaving behind a greater density of food (GUD) than it leaves when under low perceived predation risk.

We set out feeding trays in $4 \times 4$ grids with $12 \mathrm{~m}$ between trays. We randomly distributed 2 grids in each treatment area in July and October 2004. Trays were clear plastic containers (Rubbermaid ${ }^{\circledR} \# 4480 ; 43.8 \times 29.5 \times$ $16.5 \mathrm{~cm}$ ) with six 5-cm-diameter holes drilled in the sides to allow for rodent access. We filled the trays with a mixture of $1.0 \mathrm{~L}$ of commercially available sand and $10.0 \mathrm{~g}$ of shelled sunflower seeds. Rodents in our study area are primarily granivorous during the dry summer and early fall months (Batzli and Pitelka 1970, 1971). We sieved the sand twice daily (within 2 hours of sunrise and sunset) so the remaining seeds could be retrieved, cleaned of sand and debris, and weighed, and we recharged trays with $10.0 \mathrm{~g}$ of new seeds after each collection. After a 36-hour prebaiting period, we ran grids to yield 3 nocturnal and 3 diurnal GUDs per tray per sample period. Diurnal and nocturnal GUDs did not differ substantially among treatments, and previous local work indicates that rodent activity is similar between night and day (Dunk and Cooper 1994), so we report nocturnal GUDs only (i.e., nighttime foraging) because diurnal GUDs were also influenced by seed-eating birds. Some trays $(n=26)$ were disturbed by foxes in the fall (prints identified), and we excluded these trays from analysis, yielding a total sample of 102 trays (306 tray- nights). All procedures involving animals were approved by the California Department of Fish and Game and the Humboldt State University Institutional Animal Care and Use Committee (protocol numbers 03/04.W.18.A and 03/04.W .97.A).

To monitor changes in vegetation structure, we measured plant height and grass canopy cover at each bird survey station at the time of bird surveys. We recorded the height of the tallest vegetation and tallied the presence of grass cover at points using a 10-pin frame (Smith 1959).

Our study design enabled before-and-after comparisons of a treated (grazed) and an untreated (control) area (i.e., before-after, controlimpact design). As in many other studies involving large habitat manipulations, we could not replicate sites, given the availability of grasslands for study and the economic and political costs of introducing livestock to previously ungrazed public land. Therefore, our analyses demonstrate responses, but they cannot be extrapolated with known confidence to other areas (Guthery 1987). We used repeatedmeasures ANOVA to examine changes in (1) rodent abundance, (2) raptor activity, and (3) vegetation height and cover over time on the grazed and ungrazed treatments. In these analyses, the sample grid or the sample point was the subject, time period $(n=23)$ was the within-subjects time factor, and treatment (grazed or control) was the between-subjects factor. The time $\times$ treatment effect revealed if the onset of grazing altered a response variable over time relative to the ungrazed area. We used 2-way repeated measures ANOVA for the GUD analysis, in which the 3 nights served as the within-subjects time factor, and treatment and season (summer or fall) each served as between-subjects factors. We used ANOVA to compare rodent strike and capture rates between treatments, and chi-square analysis to examine differences in success rate. We did not examine species-specific attack or success rates because of limited sample sizes and because we were most interested in overall risk of predation to rodents. We used a significance level $(\alpha)$ of 0.05 for all statistical analyses. We calculated an index of the probability that a rodent was killed by a raptor during our raptor hunting surveys by using the following equation:

$$
\text { depredation }=(\text { strike } \cdot \text { success }) / \text { density, }
$$


where strike is the strike rate (strikes hour $^{-1} \mathrm{ha}^{-1}$ ) we observed, success is the percentage of those strikes that were successful, and density is the minimum abundance index (previously unmarked rodents · 100 trapnights $^{-1}$ ) we recorded during the period of raptor observations divided by the area of the trapping grid (0.36 ha). Thus, depredation (kills - hour-1 rodent $^{-1} \cdot 100$ trap-nights $\left.^{-1}\right)$ is proportional to the per capita risk of depredation from raptors during our observations. We calculated the per capita depredation risk for the ungrazed and grazed treatments separately.

\section{RESUlTS}

Before the onset of grazing, vegetation height on the grazed and ungrazed areas ranged from 63 to $76 \mathrm{~cm}$. About 6 months after the onset of grazing (February 2004), vegetation height was reduced to $15-40 \mathrm{~cm}$ on the grazed area, and it remained low for the duration of the study (treatment $\times$ time: $F_{22,132}=10.11$, $P<0.001)$. There was no main effect of treatment on vegetation height $\left(F_{1,6}=2.04, P=\right.$ $0.20)$. Grass cover was consistently high, ranging from $72 \%$ to $96 \%$. It did not differ significantly between the grazed and ungrazed treatments $\left(F_{1,6}=1.05, P=0.34\right)$ or over time $\left(F_{22,132}=1.51, P=0.08\right)$, although percent grass cover tended to be lowest in winter and highest in late summer and early fall.

We captured a total of 3119 small mammals. The species composition did not vary significantly between grazed and ungrazed treatments; overall it was comprised of Microtus californicus (California vole, 42\%), Reithrodontomys megalotis (western harvest mouse, $30 \%$ ), Sorex vagrans (vagrant shrew, $24 \%$ ), and Mus musculus (house mouse, 4\%). However, the species composition of captured animals did vary seasonally, with most $R$. megalotis captured in winter and most $S$. vagrans captured in summer months.

The abundance of rodents (i.e., voles + mice) in both areas varied significantly over time overall, with peaks in December 2003, August 2004, February 2005, and October 2005 (roughly 6-8 month intervals; within-subject time effect: $\left.F_{22,110}=19.90, P<0.001\right)$. Rodent abundance varied differently over time between grazed and ungrazed treatments (treatment $x$ time: $F_{22,110}=1.85, P=0.02$; Fig. 1). Abundance was similar on the grazed and ungrazed treatments before grazing began (August 2003) and for several months after the onset of grazing. Beginning in November 2003, the number of rodents trapped on the grazed treatment was lower than the number trapped on the ungrazed treatment. The overall effects of the experiment were driven primarily by voles, which showed a somewhat slower response to the onset of grazing than did mice (first differences emerge at 8 versus 5 months, respectively; Fig. 1). Comparing data from before and after November 2003 shows that overall rodent abundance declined by $69 \%(8.5 \pm 1.5$ to $2.6 \pm 0.9$ rodents $\cdot 100$ trap-nights $^{-1}$ ) on the grazed area and increased by $14 \%$ on the ungrazed area $(9.1 \pm 1.1$ to $10.3 \pm 1.5$ rodents $\cdot$ 100 trap-nights $\left.^{-1}\right)$. There was no statistical main effect of treatment $\left(F_{1,5}=5.85, P=\right.$ $0.06)$.

Surveys of raptor activity varied over time $\left(F_{22,132}=14.67, P<0.001\right)$; overall raptor activity was more than twice as high in fall and winter than in spring and summer (Fig. 2). At peak numbers, the species surveyed included White-tailed Kites (Elanus leucurus; 47\%, percent of observations), Short-eared Owls (Asio flammeus; $21 \%$ ), Northern Harriers (20\%), Redshouldered Hawks (Buteo lineatus; 7\%), Redtailed Hawks (Buteo jamaicensis; 3\%), and Peregrine Falcons (Falco peregrinus; 2\%). Raptor activity declined in the grazed treatment area once grazing began (treatment $\times$ time: $F_{22,132}$ $=7.45, P<0.001$; Fig. 2). Comparing data from before and after November 2003 (the month by which differences due to grazing became apparent), overall raptor activity declined by $16 \%$ on the grazed area $(0.83 \pm 0.54$ to 0.70 \pm 0.33 birds $\cdot$ point $^{-1}$ hour $^{-1}$ ) and increased by $63 \%$ on the ungrazed area $(1.10 \pm 0.86$ to 1.79 \pm 0.47 birds $\cdot$ point $^{-1}$ hour $\left.^{-1}\right)$. This pattern was largely driven by counts of White-tailed Kites and Short-eared Owls, which declined 50\%$80 \%$ on the grazed treatment after the onset of grazing; counts of other species did not differ significantly between treatments. The overall effect of grazing on raptors shows a pulsed response (i.e., differences greater in winter than in summer), largely because Shorteared Owls responded negatively to grazing but did not occur in the area in the summer. There was no main effect of treatment on raptor activity $\left(F_{1,5}=0.82, P=0.41\right)$. Raptor attack rate was over 7 times higher on the ungrazed than on the grazed treatment area 

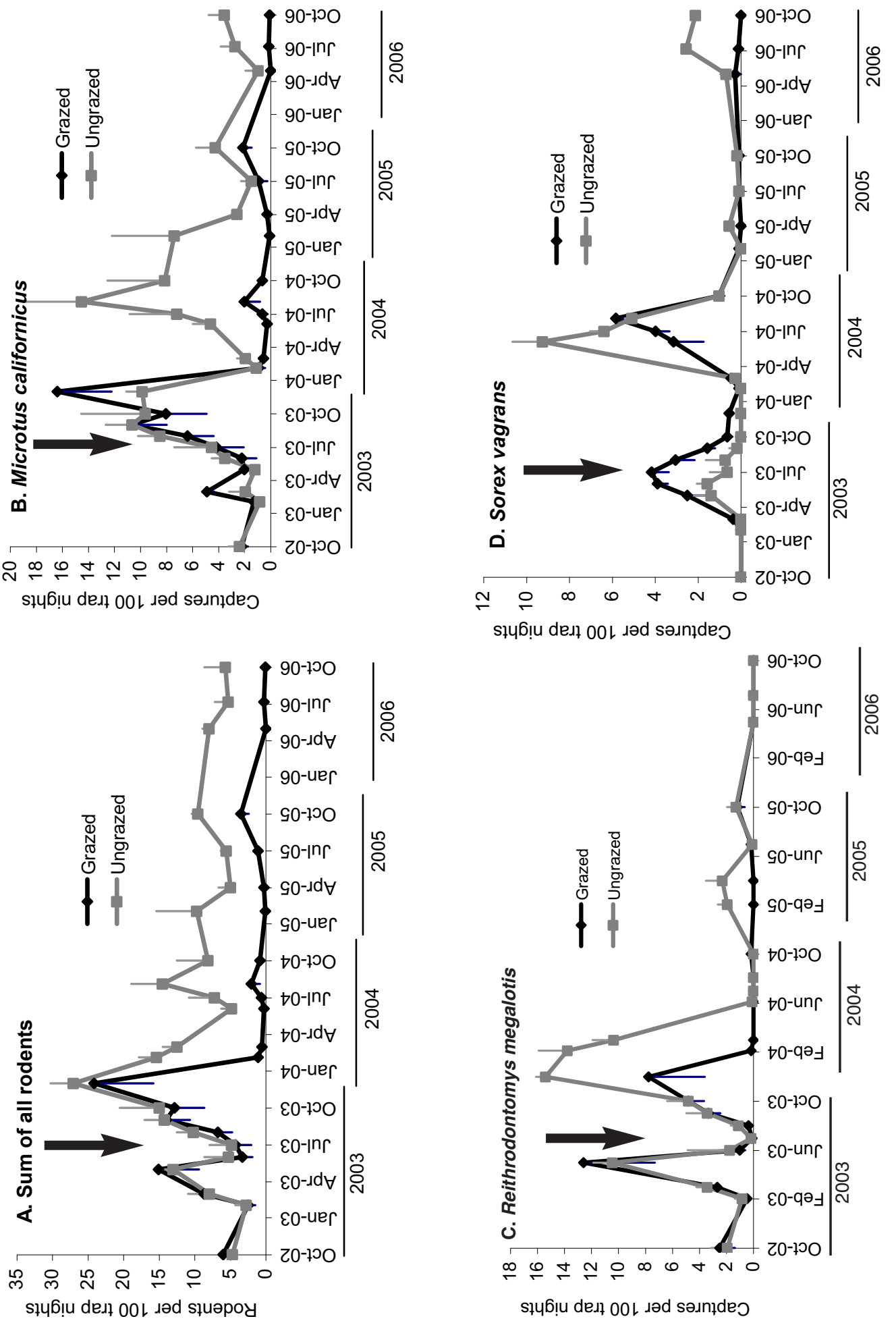

Fig. 1. Abundance index for small mammals on grazed and ungrazed treatment areas of the Mad River Slough Wildlife Area, Arcata, California, 2002-2006. Arrows depict the onset of grazing. Error bars depict one standard error around the mean; they are one-sided to avoid overlap. 


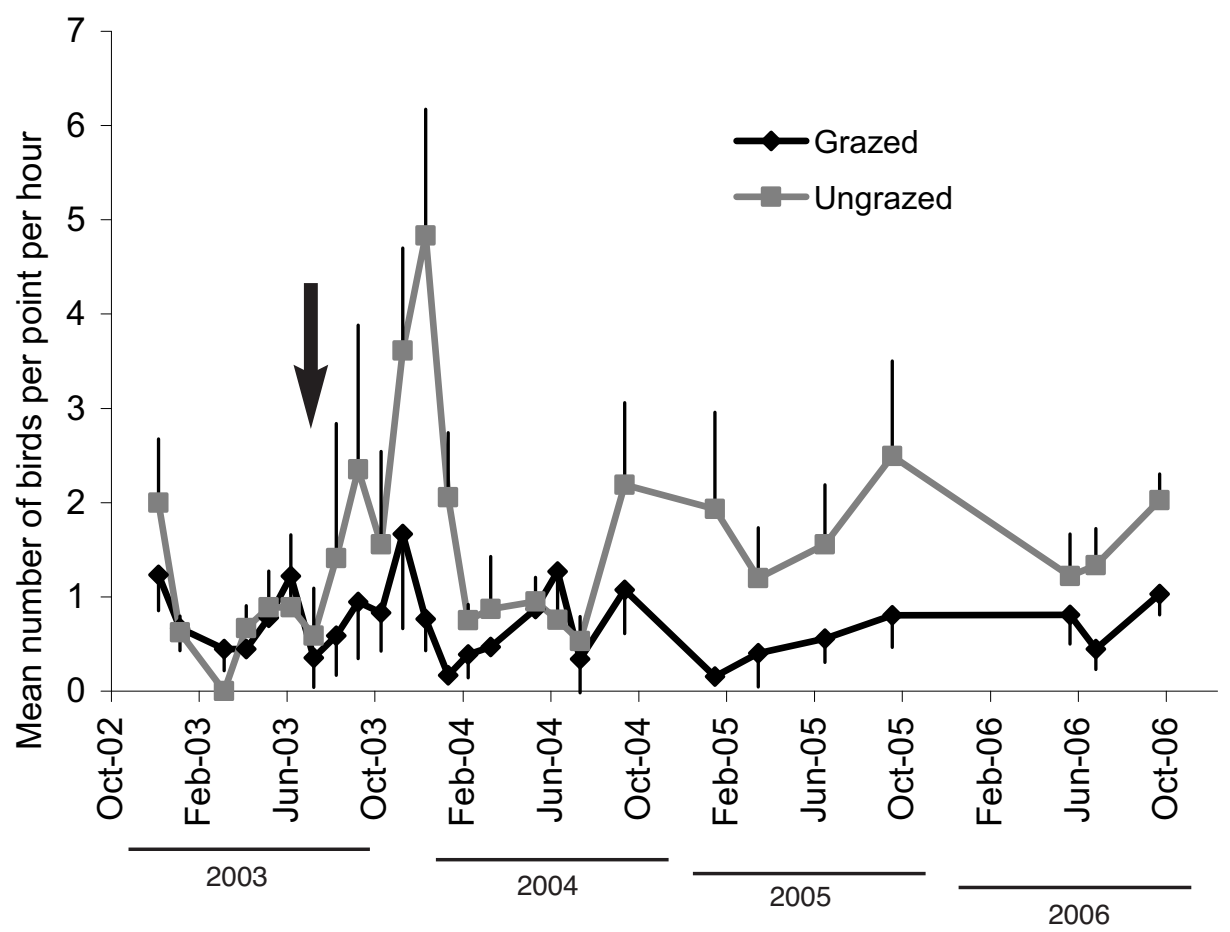

Fig. 2. Mean raptor activity on grazed and ungrazed treatment areas of the Mad River Slough Wildlife Area, Arcata California, 2002-2006. Arrow depicts the onset of grazing. Error bars depict one standard error around the mean; they are one-sided to avoid overlap.

TABLE 1. Index of per capita probability of depredation by a raptor for rodents in summer (July) and fall (October) at the Mad River Slough Wildlife Area, Arcata, California, 2004.

\begin{tabular}{|c|c|c|c|c|c|c|}
\hline Season & Treatment & $\begin{array}{l}\text { Minimum rodent } \\
\text { density index }\end{array}$ & $\begin{array}{c}\text { Raptor } \\
\text { strike rateb }\end{array}$ & $\begin{array}{c}\text { Raptor } \\
\text { success ratec }\end{array}$ & Kill rated & Depredation riske \\
\hline Fall & $\begin{array}{l}\text { Grazed } \\
\text { Ungrazed }\end{array}$ & $\begin{array}{r}9.78 \\
26.56\end{array}$ & $\begin{array}{l}0.0116 \\
0.0859\end{array}$ & $\begin{array}{l}40 \% \\
42 \%\end{array}$ & $\begin{array}{l}0.0046 \\
0.0365\end{array}$ & $\begin{array}{l}0.47 \times 10^{-3} \\
1.37 \times 10^{-3}\end{array}$ \\
\hline Summer & $\begin{array}{c}\text { Grazed } \\
\text { Ungrazed }\end{array}$ & $\begin{array}{r}3.08 \\
15.44\end{array}$ & $\begin{array}{l}0.0069 \\
0.0677\end{array}$ & $\begin{array}{l}33 \% \\
42 \%\end{array}$ & $\begin{array}{l}0.0023 \\
0.0286\end{array}$ & $\begin{array}{l}0.75 \times 10^{-3} \\
1.86 \times 10^{-3}\end{array}$ \\
\hline Summer & $\begin{array}{c}\text { Grazed } \\
\text { Ungrazed }\end{array}$ & $\begin{array}{r}6.43 \\
21.00\end{array}$ & $\begin{array}{l}0.0093 \\
0.0768\end{array}$ & $\begin{array}{l}38 \% \\
42 \%\end{array}$ & $\begin{array}{l}0.0035 \\
0.0326\end{array}$ & $\begin{array}{l}0.54 \times 10^{-3} \\
1.55 \times 10^{-3}\end{array}$ \\
\hline
\end{tabular}

aNumber of unique individuals captured: rodents $\cdot 100$ trap-nights ${ }^{-1} \mathrm{ha}^{-1}$

b Strikes $\cdot$ hour $^{-1}$ ha $^{-1}$

cPercentage of strikes that were successful

d Kills $\cdot$ hour ${ }^{-1}$ ha $^{-1}$

Kills $\cdot$ hour $^{-1}$ rodent $^{-1} \cdot 100$ trap-nights $^{-1}$

(7.68 \pm 0.54 and $0.93 \pm 0.34$ attacks $\cdot 100 \mathrm{ha}^{-1}$, respectively; $F_{1,28}=76.20, P<0.001$ ), but it did not differ significantly between summer and fall $\left(F_{1,28}=0.21, P=0.65\right)$, and there was no interaction between season and treatment $\left(F_{1,28}=1.51, P=0.23\right)$. Raptor attack success rate was $38 \%$ and $42 \%$ on the grazed and ungrazed treatments, respectively; it did not differ significantly between treatments $\left(\chi^{2}{ }_{1}=0.07, P=0.79\right)$ or between summer and fall $\left(\chi^{2}{ }_{1}=0.006, P=0.94\right)$. Our calculated index of the per capita probability of depredation by a raptor indicated that, overall, a rodent was 2.5 times more likely to be killed by a raptor in the ungrazed area than in the grazed area during our raptor foraging surveys (Table 1).

The GUD, a measure of perceived predation risk, was $12 \%$ higher in the fall than in the summer $\left(F_{1,98}=9.07, P<0.01\right.$; Table 2$)$ and 
TABLE 2. Mean $\left(\underline{t}_{\bar{x}}\right)$ giving-up density of food in depletable food trays deployed for 3 nights on grazed and ungrazed habitat in summer (July) and fall (October) at the Mad River Slough Wildlife Area, Arcata, California, 2004.

\begin{tabular}{lcrrr}
\hline & & \multicolumn{3}{c}{ Giving-up-density $(\mathrm{g})$} \\
\cline { 3 - 4 } Season & Treatment & \multicolumn{1}{c}{ Night 1 } & Night 2 & Night 3 \\
\hline \multirow{2}{*}{ Summer } & Grazed & $10.19 \pm 0.28$ & $9.99 \pm 0.33$ & $9.40 \pm 0.38$ \\
& Ungrazed & $8.58 \pm 0.27$ & $7.83 \pm 0.33$ & $6.28 \pm 0.38$ \\
Fall & Grazed & $10.79 \pm 0.32$ & $9.91 \pm 0.39$ & $10.18 \pm 0.44$ \\
& Ungrazed & $10.34 \pm 0.39$ & $9.03 \pm 0.46$ & $9.44 \pm 0.53$ \\
\hline
\end{tabular}

$25 \%$ higher on the grazed treatement than on the ungrazed treatment $\left(F_{1,98}=36.78, P<\right.$ $0.001)$. The difference between the grazed and ungrazed treatment was higher in the summer (30\% difference) than in the fall $(15 \%$ difference), but this difference was not statistically significant (season $\times$ treatment: $F_{1,98}=$ $2.43, P=0.12)$. Overall, the GUD decreased $15 \%$ over the 3 -night sample (time effect: $F_{2,196}$ $=23.78, P<0.001)$. At times GUD values exceeded $10 \mathrm{~g}$ (initial seed weight) due to moisture absorption, but this capacity did not differ significantly between grazed and ungrazed areas (C.M. Horn unpublished data).

\section{Discussion}

We demonstrated for the first time that cattle grazing reduced the abundance of rodents in a mesic coastal grassland. Rodents declined within 6 months of the onset of rotational grazing, and they remained lower in abundance for the remaining 2.5 years of the study (Fig. 1). There are 2 main factors that could explain how grazing reduces rodent numbers. First, grazing may diminish food available to rodents by creating direct competition between large and small herbivores, or by inhibiting grass seed production (Evans et al. 2006). Second, by reducing grass height and structural density, grazing could diminish vegetation cover important for thermoregulation (McCafferty et al. 2003) and predator avoidance (Smit et al. 2001). We unfortunately did not measure structural density (e.g., via a Robel pole or sward stick), but results of our grass height measurements and GUD experiments support the importance of cover from predators; rodents perceived a significantly greater predation risk on the grazed portion of our study area (Table 2). GUDs (our measure of predation risk) may also increase in response to high ambient food availability. However, seed rain, a measure of food supply for granivores, did not differ significantly between the 2 treatments in July 2004 (C.M. Horn unpublished data). Although we do not know how rodent food supply may have varied at other times of the year, the sharp decline in rodent abundance on the grazed area suggests that an increase in food is very unlikely.

Grazing also reduced raptor activity on our study area (Fig. 2), especially activity of Whitetailed Kites and Short-eared Owls, both of which are known to rely heavily on rodents for prey (Clark 1975, Dunk and Cooper 1994). The magnitude of the change was small (roughly 1 bird per point count per hour), and we do not suggest that grazing had a numerical effect on raptor abundance. Rather, we suggest that the reduction in activity was largely a functional response by which raptors altered their foraging behavior over the fields once grazing began. Although we cannot eliminate the possibility that raptors responded to the presence of cattle directly, other work suggests that their response may have been driven by changes in the availability of their rodent prey. Predators respond to both prey abundance and prey accessibility (Lima 2002), and grazing may reduce rodent abundance while enhancing their vulnerability to predators (Orrock et al. 2004). Therefore, theory suggests that rodent prey in grasslands may be, on balance, most available to raptors at intermediate levels of grazing (Bouskila 2001, Evans et al. 2006). However, the grazing intensity in this study clearly did not enhance prey accessibility. Raptor attack rates were significantly lower on the grazed than on the ungrazed area, and success rate $(\sim 40 \%)$ did not vary significantly between the treatments, resulting in a much lower kill rate on the grazed area. Thus, grazing appears to have reduced the quality of foraging habitat for raptors in our study area. This may have caused birds to concentrate their activity on 
the ungrazed habitat rather than abandon the area altogether. Our data showed that after grazing began, raptor activity on the ungrazed habitat increased by $63 \%$, while rodent abundance increased there only by $14 \%$.

Our findings suggest that rodents used indirect vegetative cues, such as grass height, to assess predation risk on our study area. The GUD results indicated that perceived predation risk was significantly higher in the grazed area than in the ungrazed area. However, our calculations revealed that because raptors hunted so rarely over the grazed area, the actual per capita probability that a rodent may be killed by a diurnal raptor was about 2.5 times lower on the grazed area. This apparent paradox could be reconciled by opposing patterns of depredation from other predators (e.g., greater risk from owls, foxes, etc., on the grazed side). Barn owls (Tyto alba), gray foxes (Urocyon cinereoargenteus), and striped skunks (Mephitis mephitis) are all common at the study site, and bobcats (Felis rufus) and mink (Mustela vison) have also been observed. Alternatively, rodents may perceive predation risk indirectly by monitoring vegetative structure and responding accordingly, regardless of other direct cues (e.g., number of predators) or true risk of death (Bouskila and Blumstein 1992). Orrock et al. (2004) found that mice at the Savannah River site in North Carolina perceived predation risk as a function of vegetative cover and moon phase and were unresponsive to experimental direct cues (urine from predators). In our study, rodents perceived greater risk in fall than in summer, in correspondence with greater use of the study area by raptors. This could be because the rodents responded directly to visible raptor activity, but indirect cues such as changes in photoperiod may also be responsible and are probably more feasibly assessed by a rodent than indirect cues are. In general, it may be more reliable for prey to use indirect cues than direct cues to assess risk from multiple vertebrate predators in open environments such as grasslands (Kotler et al. 1991). Additional work should focus on quantifying the true risk of rodent depredation from a variety of vertebrate predators under different grassland structures. Grass cover tended to be higher in fall than in summer, so greater perceived risk in fall is unlikely to be a result of reduced concealment from vegetation.

\section{ACKNOWLEDGMENTS}

Financial support was provided by the California State Coastal Conservancy, California Department of Fish and Game, and Humboldt State University. C. Bartolotta, P. Bussman, S. Corbaley, K. Fulgham, K. Kovacs, D. Santos, K. Zeimer, the Humboldt County Farm Bureau, the National Resource Conservation Service, and the California Department of Fish and Game provided logistical support. Fieldwork was conducted with an army of over 40 undergraduate and graduate students from HSU; special thanks go to W. Crombie, L. Hagenauer, and T. Penland. We dedicate this manuscript in loving memory to Braden Hogan, who always brought a smile into the field. This manuscript benefitted from constructive comments by $\mathrm{M}$. Morrison and an anonymous reviewer.

\section{Literature Cited}

Batzli, G.O., AND F.A. PitelKa. 1970. Influence of meadow mouse populations on California grassland. Ecology 51:1027-1039.

1971. Condition and diet of cycling populations of the California vole, Microtus californicus. Journal of Mammalogy 52:141-163.

Bock, C.E., AND J.H. Bock. 1999. Response of winter birds to drought and short-duration grazing in southeastern Arizona. Conservation Biology 13:1117-1123.

Bock, C.E., J.H. Bock, W.R. Kenney, and V.M. HaWTHORNE. 1984. Response of birds, rodents, and vegetation to livestock exclosure in a semidesert grassland site. Journal of Range Management 37:239-242.

Bock, C.E., Z.F. Jones, AND J.H. Bock. 2006. Rodent communities in an exurbanizing southwestern landscape (U.S.A.). Conservation Biology 20:1242-1250.

Bouskila, A. 2001. A habitat selection game of interactions between rodents and their predators. Annales Zoologici Fennici 38:55-70.

Bouskila, A., AND D.T. Blumstein. 1992. Rules of thumb for predation hazard assessment: predictions from a dynamic model. American Naturalist 139:161-176.

Brown, J.S., AND B.P. KotLER. 2004. Hazardous duty pay and the foraging costs of predation. Ecology Letters 7:999-1014.

Carroll, L.C., T.W. Arnold, and J.A. Beam. 2007. Effects of rotational grazing on nesting ducks in California. Journal of Wildlife Management 71:902-905.

Clark, R.J. 1975. A field study of the Short-eared Owl (Asio flammeus) (Pontoppidan) in North America. Wildlife Monographs 47:1-67.

Crocoll, S.T. 1994. Red-shouldered Hawk (Buteo lineatus). Account 107 in A. Poole and F. Gill, editors, The birds of North America. Academy of Natural Sciences, Philadelphia, PA, and American Ornithologists' Union, Washington, DC.

DunK, J.R. 1995. White-tailed Kite (Elanus leucurus). Account 178 in A. Poole and F. Gill, editors, The birds of North America. Academy of Natural Sciences, 
Philadelphia, PA, and American Ornithologists Union, Washington, DC.

Dunk, J.R., AND R.J. CoOper. 1994. Territory-size regulation in Black-shouldered Kites. Auk 111:588-595.

Evans, D.M., S.M. Redpath, D.A. Elston, S. Evans, R.J. Mitchell, And P. Dennis. 2006. To graze or not to graze? Sheep, voles, forestry and nature conservation in the British uplands. Journal of Applied Ecology 43:499-505.

Fehmi, J.S., And J.W. Bartolome. 2002. Species richness and California voles in an annual and a perennial grassland. Western North American Naturalist 62:7381.

Fleischner, T.L. 1994. Ecological costs of livestock grazing in western North America. Conservation Biology 8:629-644.

GutherY, F.S. 1987. Guidelines for preparing and reviewing manuscripts based on field experiments with unreplicated treatments. Wildlife Society Bulletin 15:306.

Hayes, G.F., and K.D. HolL. 2003. Cattle grazing impacts on annual forbs and vegetation composition of mesic grasslands in California. Conservation Biology 17: 1694-1702.

Hopkins, H.L., AND L.L. KenNedy. 2004. An assessment of indices of relative and absolute abundance for monitoring populations of small mammals. Wildlife Society Bulletin 32:1289-1296.

IgNatiuk, J.B., AND D.C. DunCAN. 2001. Nest success of ducks on rotational and season-long grazing systems in Saskatchewan. Wildlife Society Bulletin 29:211217.

Jones, A. 2000. Effects of cattle grazing on North American arid ecosystems: a quantitative review. Western North American Naturalist 60:155-164.

Jones, Z.F., C.E. Bock, AND J.H. Bock. 2003. Rodent communities in a grazed and ungrazed Arizona grassland, and a model of habitat relationships among rodents in Southwestern grass/shrublands. American Midland Naturalist 149:384-394.

KANTRUD, H.A. 1986. Effects of vegetation manipulation on breeding waterfowl in prairie wetlands-a literature review. U.S. Fish and Wildlife Service, Fish and Wildlife Technical Report 3, Washington, DC.

Kirby, R.E., J.K. Ringelman, D.A. Anderson, and R.S. SoJDA. 1992. Grazing on national wildlife refuges: do the needs outweigh the problems? Transactions of the North American Wildlife and Natural Resources Conference 57:611-626.

Kotler, B.P., J.S. Brown, AND O. Hasson. 1991. Factors affecting gerbil foraging behavior and rates of owl predation. Ecology 72:2249-2260.

Lima, S.L. 2002. Putting predators back into behavioral predator-prey interactions. Trends in Ecology and Evolution 17:70-75.
MacWhirter, R.B., and K.L. Bildstein. 1996. Northern Harrier (Circus cyaneus). Account 210 in A. Poole and F. Gill, editors, The birds of North America. Academy of Natural Sciences, Philadelphia, PA, and American Ornithologists' Union, Washington, DC.

McCafferty, D.J., J.B. MoncriefF, and I.R. Taylor. 2003. Winter microclimate of field voles (Microtus agrestis) in SW Scotland. Journal of Thermal Biology 28:397-401.

[NOAA] National Oceanic and Atmospheric AdminisTRATION. 2007. National Weather Service Climate Data [accessed 23 July 2007]. Available from: http://www.weather.gov/climate/index.php?wfo=eka.

Newton, I. 1998. Population limitation in birds. Academic Press, San Diego, CA.

Orrock, J.L., B.J. Danielson, and R.J. Brinkerhoff. 2004. Rodent foraging is affected by indirect, but not by direct, cues of predation risk. Behavioral Ecology 15:433-437.

Ostfeld, R.S., AND L.L. KLOSTERman. 1986. Demographic substructure in a California vole population inhabiting a patchy environment. Journal of Mammalogy 67:693704.

Preston, C.R., and R.D. Beane. 1993. Red-tailed Hawk (Buteo jamaicensis). Account 52 in A. Poole and F. Gill, editors, The birds of North America. Academy of Natural Sciences, Philadelphia, PA, and American Ornithologists' Union, Washington, DC.

Redpath, S., A. Amar, M. Madders, F. Leckie, and S. THirgood. 2002. Hen harrier foraging success in relation to land use in Scotland. Animal Conservation 5:113-118.

SAAB, V.A., C.E. Bock, T.D. Rich, and D.S. DobKin. 1995. Livestock grazing effects in western North America. Pages 311-353 in T.E. Martin and D.M. Finch, editors, Ecology and management of neotropical migratory birds. Oxford University, New York.

SEvErSon, K.E. 1990. Summary: livestock grazing as a management tool. Pages 3-6 in K.E. Severson, technical editor, Can livestock be used as a tool to enhance wildlife habitat? General Technical Report RM-194, USDA Forest Service, Rocky Mountain Forest and Range Experiment Station, Fort Collins, CO.

Smit, R., J. Bokdam, J. den Ouden, H. Olff, H. SchotOpschoOr, AND M. Schrijvers. 2001. Effects of introduction and exclusion of large herbivores on small rodent communities. Plant Ecology 155:119_ 127.

Sмith, J.G. 1959. Additional modification of the point frame. Journal of Range Management 12:204-205.

Received 7 December 2007 Accepted 7 April 2008 